\title{
Potential Effects of Cranberry Extract Against Lead Acetate-Induced Hepato-Renal'Toxicity in Rats
}

\author{
Hussein Ibrahim El-belbasy ${ }^{1}$, Mohammed Abdalla Hussein², Mohamed El-mitwaly \\ Alghitany $^{3 *}$
}

${ }^{1}$ Biochemistry Department, Faculty of VeterinaryMedicine, Zagazig University-44519, Zagazig, Egypt; ${ }^{2}$ Biochemistry Department, Faculty of Applied Medical Sciences, October $6^{\text {th }}$ University-12585, Giza, Egypt; ${ }^{3}$ Medical Laboratory Department, Faculty of Applied Medical Sciences, October $6^{\text {th }}$ University-12585, Giza, Egypt.

\begin{abstract}
Lead $(\mathrm{Pb})$ has been identified as a hazardous heavy metal and a pollutant in the environment, especially due to its human activity. It poisons several physiological systems, such as the hepatic, renal, reproductive, as well as nervous systems, because of an elevation in oxidative damage caused by the formation of reactive oxygen species (ROS). Cranberry is a powerful antioxidant in addition to being a component of an anti-inflammatory disease treatments. The goal of this study was to see if cranberry extract could protect rats from toxicity caused by lead acetate. Addition of cranberry extract at a dose of 75 and $150 \mathrm{mg} / \mathrm{kg}$ to rats allowed to treat with lead acetate at a dose of $50 \mathrm{mg} / \mathrm{kg}$ to 6 weeks significantly protected the rats from the lead acetate-induced increase in both serum alanine aminotransferase (ALT), aspartate aminotransferase (AST), lactate dehydrogenases (LDH), total and direct bilirubin, alkaline phosphatase (ALP), creatinine, urea, total cholesterol (TC), triglycerides (TG), LDL-C and VLDL-C in addition against an elevation of serum glucose, tumor necrosis factor-alpha (TNF- $\alpha$ ) and malondialdehyde (MDA). Treatment with cranberry extract at a dose of 75 and $150 \mathrm{mg} / \mathrm{kg}$ also led to a valuable rise in serum total soluble protein, albumin, globulin, HDL-C, triiodothyronine (T3), total thyroxine (T4) as well as hepatic and renal tissue of reduced glutathione (GSH), superoxide dismutase (SOD), catalase activity (CAT) and total antioxidant capacity (TAC) as compared to lead acetate-treated rats. Cranberry has hepato-renal protective impacts in restoring liver and kidney function, according to histopathological evaluation of hepatic and renal tissues. These findings have shown, in conclusion, that cranberry extract has such a strong protective effect in rats suffering from hepato-renal toxicity caused by lead acetate.
\end{abstract}

Keywords | Cranberry extract, Lead acetate, Hepato-renal toxicity, Oxidative stress, Oxidative stress biomarkers

Received | June 02, 2021; Accepted | July 10, 2021; Published | August 25, 2021

*Correspondence | Mohamed El-mitwaly Alghitany, Medical Laboratory Department, Faculty of Applied Medical Sciences, October $6^{\text {th }}$ University - 12585, Giza, Egypt; Email: m.alghitany90@gmail.com

Citation | El-belbasy HI, Hussein MA, Alghitany ME-M (2021). Potential effects of cranberry extract against lead acetate-induced hepato-renal toxicity in rats. Adv. Anim. Vet. Sci. 9(10): 1669-1683

DOI | http://dx.doi.org/10.17582/journal.aavs/2021/9.10.1669.1683

ISSN (Online) | 2307-8316; ISSN (Print) | 2309-3331

Copyright $(9) 2021$ El-belbasy et al. This is an open access article distributed under the Creative Commons Attribution License, which permits unrestricted use, distribution, and reproduction in any medium, provided the original work is properly cited.

\section{INTRODUCTION}

$\mathrm{O}$ ne of the most pressing issues confronting humanity today is environmental pollution (Ali and Khan, 2017). Numerous epidemiological studies have reported a strong relationship to human hepatic and renal damage and exposure to multiple environmental pollutants (Gao et al., 2015). Heavy metals enter the environment, pollute food supply and induce a variety of health issues because of their toxic effects. Prolonged exposure to such toxic metals puts living organisms in grave danger (WieczorekDa browska et al., 2013).

Lead is a great source of threat for public health as one of the most toxic environmental pollutants stable (Andjelkovic et al., 2019). According to Soliman et al. 
(2015), lead (Pb) has a high risk of causing hepatotoxicity as well as nephrotoxicity in most animal and human species. Because it is widely used in the production of materials like pigments, plastic batteries, fuel oil, cosmetics, tank connections, piping, poetry glassing, and dolls, it is regarded a significant toxic substance for the environment (ATSDR, 2007; WHO, 2010). The principal modes of exposure to lead in the ecosystem are through ingestion and inhalation of its particles, whereas in fewer cases it is through skin and prenatal exposure (Dapul and Laraque, 2014; ATSDR, 2017). Lead builds up in animal tissues like the liver, the kidney and the bones and these organs are often examined in wildlife toxicology experiments (Plaza et al., 2018).

Oxidative stress is defined as the difference between both the reactive oxygen species (ROS) formation and the antioxidants for free radicals (Costa et al., 2015; Fenga et al., 2016). The main toxic effects of lead are elevated ROS levels (Flora et al., 2012). This could occur by 2 distinct methods. The first route is the $\delta$-aminolevulinic acid dehydratase $(\delta$-ALAD) pro-oxidant effect. The Second pathway is linked to lead's direct effect on cell membranes' lipid composition (Ahamed and Siddiqui, 2007; Lopes et al., 2016). Latest studies reveal that reactive oxygen species (ROS) play an integral part in the nephrotoxicity caused by lead (Xu et al., 2008; Mervat et al., 2012). If lead damages the kidneys, it is referred to as "lead-related nephrotoxicity" by physicians. Throughout the renal tubules, lead is taken up by proximal tubules, in which many of the associated proteins associated with lead. Intercellular inclusions of proximal tubular cells are generated by these lead-binding proteins (Kwon et al., 2015).

Lead poisoning causes the normal anatomical organisation of hepatic lobules to be disrupted, as well as the disruption of the characteristic cord-like liver cells structure, hepatocytes that are hyperchromatic with transverse vacuoles, and congestion caused by sinuses (Bukola et al., 2015). According to Abdel Moneim (2016), Lead acetate caused primary hepatic cell death which was followed by the expansion of the sinuses in the blood and central veins congested, and acute inflammatory cells incursion, primarily throughout the core region, also the disorder sling liver cells with nuclei bloated nuclear, emptying liver cells, and change fatty (steatosis), that included fat accumulation within cells. Abdel Moneim (2016) and Shatha et al. (2016) found a notable rise in free radical production, liver transaminase activities (ALT and AST), as well as total bilirubin levels in male Wistar rats exposed to experimental lead-induced poisoning. Fluidity of the microsomal membrane in the liver, ROS formation, as well as hepatocytic histogram variation were all associated with increased serum ALT and AST action (Shatha et al.,

\section{6).}

Plants including such Flavonoids, rutines, glycosides, terpenoids, tannins and alkaloids are present in various kind of bioactive compounds, which act as antioxidants in stressful situations and have important protective properties such as antitumor, anti-inflammative, anti-mutagenic and immunomodular anti-hepatic toxicity (Blumberg et al., 2013). Cranberries are one of these plants, and they've long been prized for their medicinal properties. Native Americans used them to treat bladder and kidney problems. Cranberries contain a variety of bioactive compounds, including fructose, vitamin $\mathrm{C}$, flavonoids, anthocyanidins, catechins, triterpenoids, and phenolic compounds, which are widely used for their health benefits and anti-cancer properties (Hisano et al., 2012).

Cranberry's flavonoids scavenge free radicals, superoxide radicals, hydroxyl radicals, and lipid peroxidation, preventing mitochondrial destruction, degradation, and membrane integrity loss (Lapshina et al., 2015). Previous research has found that flavonoids in cranberry extract (CBE) have the ability to lower ALT and AST elevated concentrations and inhibit lipid membrane droplet buildup in rat liver models (Cheshchevik et al., 2012). Cranberry extract powder ( $\mathrm{CBE}$ ) is also used in food to boost the body's antioxidant defenses.

The polyphenol compounds found in Vaccinium macrocarpon (American cranberry) possess tremendous and valuable properties against both infections, tumors, cancers and mutations. These polyphenols' concentration in cranberries increases as the fruit ripens and the size of the fruit grows. Anthocyanins contain six aglycones. Phenolic acid, which includes hydroxybenzoic acid and hydroxycinnamic acid, is the second most prevalent compound in CBE. However, benzoic acid is found in significant quantities. Just three forms of hydroxybenzoic acid are found in smaller amounts: 2, 4-dihydroxybenzoic, p-hydroxybenzoic, and ohydroxybenzoic. Likewise, the hydroxycinnamic also includes different ingredients like pcoumar, ferulic acid, sinapic and caffeic. Terpenes are the third most plentiful bio-active compound but research on them has been limited compared to the polyphenolic composition. Flavonols can be found in cranberry fruit, but elderberry has a higher concentration (Hafez et al., 2014).

Cranberry extract's protective function in lead acetate (LD)-induced hepato-nephrotoxicity has yet to be fully investigated. As a result, the objective of this work was to evaluate the protective and therapeutic potential effects of cranberry extract in rats with hepato-renal toxicity caused by lead poisoning. 


\section{MATERIALS AND METHODS}

\section{Chemicals And other Reagents}

Company of Sigma Chemical supplied the lead acetate (St. Louis, MO, USA). Prior to administration, the lead was diluted with distilled water. The other chemicals utilized in this investigation were all analytical quality, kept in a controlled environment, and obtained from well-known commercial sources.

\section{Plant Material}

Virgin Extracts (TM), China, provided the cranberry water extract (CBE). Cranberry was supplied a period of six weeks to adult rats daily via oral gastric gavage tube at a dose of $75 \mathrm{mg} / \mathrm{kg}(1 / 150 \mathrm{LD} 50)$ and $150 \mathrm{mg} / \mathrm{kg}(1 / 75$ LD50).

\section{CBE ANALYSIS BY GASEOUS CHROMATOGRAPHY/ MASS} SPECTROMETER (GC-MS)

At the Mycology and Biotechnology Regional Center, Al-Azhar University, in Nasr city, Cairo, Egypt, the cranberry extract chemical composition was determined using a detectable GC1310-ISQ mass spectrometer (Thermo Scientific, Austin, TX, United states). A direct capillary column TG-5MS $(30 \mathrm{~m} \times 0.25 \mathrm{~mm} \times 0.25 \mathrm{~m}$ film thickness) was used in the GC-MS scheme. At first, the temperature of column oven was maintained at $50^{\circ} \mathrm{C}$, after which increased at a rate of $5^{\circ} \mathrm{C} / \mathrm{min}$ to $230^{\circ} \mathrm{C}$, held for two minutes, and then boosted at a rate of $30^{\circ} \mathrm{C} / \mathrm{min}$ to $290^{\circ} \mathrm{C}$, held for two minutes. Temperatures for injection and MS transmission lines were maintained at 250 and 260 degrees Celsius, respectively, and Helium was utilized as a carriage gas at a regular flow speed of $1 \mathrm{ml} / \mathrm{min}$. The solvent time limit was three minutes and the Auto sampler AS1300 injected $1 \mu \mathrm{L}$ diluted samples automatically in the split mode together with GC. In full scan mode, EI mass spectrum was captured over the range of $\mathrm{m} / \mathrm{z} 40-1000$ at 70 $\mathrm{eV}$ ionization voltages. The temperature of the ionization chamber was established to $200^{\circ} \mathrm{C}$. By comparing the stability times and mass spectrometry of the components to those of the WILEY 09 and NIST 11 mass spectral databases, the elements were detected.

\section{Animal STUdy}

ETHICAL ISSUES

The present study has already been authorized by the Zagazig University's institutional Animal Care and Use Committee with the authorization number (ZUIACUC/2/F/169/2019).

\section{Animals}

The experimental investigation of this study used a total number of 40 male adult albino rats weighing approximately $200 \pm 20 \mathrm{gms}$, obtained from the Central
Animal House, Faculty of Veterinary Medicine, Zagazig University. They were allowed to acclimatize for 2 weeks. They were kept at $22 \pm 2{ }^{\circ} \mathrm{C}$ and humidity of $60 \%$ for a 12-hours light-dark period in stainless steel cages in a controlled environmentally-conditioned area. During the adaptation phase, each animal was fed an ad libitum diet (Dyets Inc., Bethlehem, PA) and had free access to water.

\section{EXPERIMENTAL DESIGN}

After acclimatization, rats were divided into four groups (10 rats per group) and given an oral daily dose by gavage method of various treatments.

\section{GROUP I (NORMAL CONTROL GROUP)}

Each rat was given $1 \mathrm{ml}$ of distilled water orally for 6 weeks (Abdel-Maksoud et al., 2015a).

\section{Group II (POSITIVE CONTROL GROUP)}

Each rat was given lead acetate at a dose of $50 \mathrm{mg} / \mathrm{kg}$ orally for 6 weeks (Sri et al., 2017).

\section{Group III}

Each rat was given lead acetate at a dose of $50 \mathrm{mg} / \mathrm{kg}$ followed by cranberry extract suspended in distilled water at a dose of $75 \mathrm{mg} / \mathrm{kg}$ for 6 weeks (Abdel-Maksoud et al., 2015a).

\section{Group IV}

Each rat was given lead acetate at a dose of $50 \mathrm{mg} / \mathrm{kg}$ followed by cranberry extract suspended in distilled water at a dose of $150 \mathrm{mg} / \mathrm{kg}$ for 6 weeks (Abdel-Maksoud et al., 2015a).

\section{BLOOD SAMPLES}

After the experiments ended, each group of rats was fasted nightly, weighted, then euthanized via cervical dislocation. Blood was drawn in glass test tube (without EDTA) and left at the room temperature to coagulate for 20 min until centrifugation on $3000 \mathrm{rpm}$ for ten min. The serum has been carefully obtained and deposited at $-20^{\circ} \mathrm{C}$ until biochemical tests have been further used (in 2 weeks). The serum that was collected was used to estimate serum alanine aminotransferase (ALT) (Reitman and Frankel, 1957), aspartate aminotransferase (AST) (Reitman and Frankel, 1957), lactate dehydrogenases (LDH) (Buhl and Jackson, 1978), total and direct bilirubin (Mashige et al., 1981), alkaline phosphatase (ALP) (Tietz, 1983), total soluble protein (Yatzidis, 1977), albumin (Doumas and Biggs, 1972), globulin, creatinine (Henry, 1974), urea (Batton and Crouch, 1977), total cholesterol (TC) (Allain et al., 1974), triglycerides (TG) (Fossati and Prencipe, 1982), HDL-C (Shih et al., 2000), LDL-C (Friedewald et al., 1972), VLDL-C (Friedewald et al., 1972), glucose (Trinder, 1969), triiodothyronine (T3) (Tammas and 
Daniel, 2009), total thyroxine (T4) (Berbel et al., 2010), and tumor necrosis factor-alpha (TNF- $\alpha)$ (Beyaert and Fiers, 1998) levels.

\section{Preparation of LiVER AND Renal SAMPLeS}

After collecting blood samples, the liver and kidneys were removed and rinsed in sodium chloride solution (0.9\%) then subdivided into two sections.

- First parts were collected and washed in distilled water and then homogenised for $15 \mathrm{~min}$ at $3000 \mathrm{rpm}$ at $4^{\circ} \mathrm{C}$ before analysis with ten-fold quantity of physiological saline. The fractions of supernatants have been isolated and deposited at $-20^{\circ} \mathrm{C}$ to assess reduced glutathione (GSH) (Beutler et al., 1963), superoxide dismutase (SOD) (Nishikimi et al., 1972), catalase activity (CAT) (Aebi, 1984), malondialdehyde (MDA) (Ohkawa et al., 1979), and total antioxidant capacity (TAC) (Koracevic et al., 2001).

- The second part was fixed in a $10 \%$ neutral formalin solution at room temperature then processed for tissue analysis.

\section{Histological assessment}

Specimens from the rats liver and kidney have been taken then preserved inside a $15 \%$ neutral-buffered formalin solution for $48 \mathrm{~h}$, dried in progressively rising ethanol (from 70 to $100 \%$ ), cleaned in xylene, then inserted in paraffin-wax. A microtome was used to cut down five $\mu \mathrm{m}$ thickness paraffin (Leica RM 2155, England). The last step, the slides had been obtained then normally dyed using hematoxylin and eosin (HE) stains (Suvarna et al., 2018). The images had been captured with a Leica ${ }^{\circledR}$ microscopy and an AmScope ${ }^{\circledR}$ digital microscope camera. Lesions Score system was created as follows: system (-= -No Alterations 0\%, $+=$ Mild Alterations 10-35\%, $++=$ Moderate Alterations $40-50 \%,+++=$ Severe and $++++=$ Intense Alterations up to $60 \%$ ).

\section{AnAlYTiCAl STATISTICS}

SPSS version 25 was used to analyze all of the data (Armonk, NY: IBM Corp). The data have been shown as a mean \pm SE. For certain parameters, a one-way ANOVA was used to see if there were any differences between groups. The post-hock test was done using Duncan's multiple range test. It was statistically significant if $\mathrm{P}<0.05$.

\section{RESULTS AND DISCUSSION}

\section{CBE ANALYSIS BY GASEOUS CHROMATOGRAPHY/MASS SPECTROMETER (GC-MS)}

The Gas chromatography-mass results for cranberry extract oil samples, displayed in (Table 1), which revealed qualitative and quantitative variation in the chemical composition. In cranberry extract compounds were identified which accounted for $29.33 \%$ of stearic acid, 10.44\% Palmitic acid, 3\% Oleic acid, 7.59\% Myristic acid, $6.94 \%$ furfural, $4.84 \%$ marphinan, $5.05 \%$ tridemorph, $3.81 \%$ oxirane, $1.68 \%$ docosane, $1.7 \%$ lycopene, $19.97 \%$ Methyl furfural, 2.56\% D-glucital, 1.5\% glycan, 2.5\% Dimethyl propanol and $1.22 \%$ siloxane.

Table 1: Chemical composition of cranberry extract.

\begin{tabular}{|lll|}
\hline RT & Compound Name & \% \\
\hline 5.28 & Stearic acid & 29.33 \\
6.41 & Palmitic acid & 10.44 \\
\hline 6.74 & Furfural & 6.94 \\
10.73 & Morphinan & 4.84 \\
13.92 & Tridemorph & 5.05 \\
15.75 & Oxirane & 3.81 \\
15.94 & Docosane & 1.68 \\
18.02 & Lycopene & 1.7 \\
\hline 19.30 & Methyl furfural & 19.97 \\
21.71 & D-glucital & 2.56 \\
23.45 & Glycan & 1.5 \\
\hline 27.17 & Myristic acid & 7.59 \\
35.23 & Dimethyl propanol & 2.5 \\
39.46 & Oleic acid & 3 \\
57 & Siloxane & 1.22 \\
\hline
\end{tabular}

\section{EFFECTS ON SERUM BIOCHEMICAL ASSAYS}

The results displayed in (Table 2) revealed a significantly difference in serum alanine aminotransferase (ALT), aspartate aminotransferase (AST), lactate dehydrogenase $(\mathrm{LDH})$, alkaline phosphatase (ALP), total soluble protein, albumin and globulin levels $(\mathrm{P}<0.001)$ and also in serum total and direct bilirubin levels $(\mathrm{P}<0.0001)$ between the four groups treated. In comparison with normal control group, oral intake of lead acetate at a dose of $50 \mathrm{mg} / \mathrm{kg}$ led to a substantial rise in serum alanine aminotransferase (ALT), aspartate aminotransferase (AST), lactate dehydrogenase (LDH), total bilirubin, direct bilirubin and alkaline phosphatase (ALP) levels, and also a substantial reduction in the levels of total soluble protein, albumin and globulin in serum. In comparison to the group that received lead acetate, addition of 75 and $150 \mathrm{mg} / \mathrm{kg}$ cranberry extract led to a marked decrease in serum alanine aminotransferase (ALT), aspartate aminotransferase (AST), lactate dehydrogenase (LDH), total bilirubin, direct bilirubin, alkaline phosphatase (ALP) levels as well as a marked rise in total soluble protein, albumin and globulin levels in serum.

The findings in (Table 3) indicated a significantly difference in serum creatinine $(\mathrm{P}<0.001)$ as well as serum urea $(\mathrm{P}<0.0001)$ levels among the four treated groups. 
In comparison with normal control group, oral intake of lead acetate at a dose of $50 \mathrm{mg} / \mathrm{kg}$ led to a substantial rise in serum creatinine and urea levels. In comparison to the group that received lead acetate, addition of 75 and 150 $\mathrm{mg} / \mathrm{kg}$ cranberry extract led to a marked decrease in serum creatinine and urea levels.

The data of (Table 4) demonstrated there had been a highly significant variation in serum total cholesterol (TC), triglycrides (TG), HDL-C, LDL-C as well as VLDL-C levels among the four treated groups $(\mathrm{P}<0.001)$.
In comparison with normal control group, oral intake of lead acetate at a dose of $50 \mathrm{mg} / \mathrm{kg}$ led to a substantial rise in serum total cholesterol (TC), triglycrides (TG), LDL-C and VLDL-C levels. Also, the level of HDL-C in serum has decreased significantly. In comparison to the group that received lead acetate, addition of 75 and 150 $\mathrm{mg} / \mathrm{kg}$ cranberry extract led to a marked decrease in serum total cholesterol (TC), triglycrides (TG), LDL-C and VLDL-C. Also, the level of serum HDL-C has increased significantly.

Table 2: Effect of cranberry extract on serum alanine aminotransferase (ALT), aspartate aminotransferase (AST), lactate dehydrogenases (LDH), total and direct bilirubin, alkaline phosphatase (ALP), total soluble protein, albumin and globulin levels in normal and experimental groups of rats.

\begin{tabular}{|c|c|c|c|c|}
\hline Groups parameters & Normal group & $\begin{array}{l}\text { Positive control (lead } \\
\text { acetate } 50 \mathrm{mg} / \mathrm{kg} \text {.b.w.) }\end{array}$ & $\begin{array}{l}\text { Lead acetate }(50 \mathrm{mg} / \\
\text { kg.b.w. })+ \text { Cranberry } \\
\text { extract }(75 \mathrm{mg} / \mathrm{kg})\end{array}$ & $\begin{array}{l}\text { Lead acetate }(50 \mathrm{mg} / \\
\mathrm{kg} \cdot \mathrm{b} . \mathrm{w} .)+ \text { Cranberry } \\
\text { extract }(150 \mathrm{mg} / \mathrm{kg})\end{array}$ \\
\hline ALT (U/L) & $16 \pm 0.70^{\mathrm{d}}$ & $63 \pm 2.82^{\mathrm{a}}$ & $44.60 \pm 1.86^{\mathrm{b}}$ & $27.40 \pm 2.01^{\mathrm{c}}$ \\
\hline AST (U/L) & $21.40 \pm 1.02^{\mathrm{d}}$ & $71.60 \pm 4.11^{\mathrm{a}}$ & $60 \pm 2.38^{b}$ & $38 \pm 1.87^{c}$ \\
\hline $\mathrm{LDH}(\mathrm{U} / \mathrm{L})$ & $1120 \pm 9.88^{\mathrm{d}}$ & $1530.6 \pm 31.05^{\mathrm{a}}$ & $1378.2 \pm 10.24^{b}$ & $1241.8 \pm 18.30^{c}$ \\
\hline Total bilirubin (mg/dl) & $2.61 \pm 0.07^{\mathrm{d}}$ & $4.98 \pm 0.16^{\mathrm{a}}$ & $4.01 \pm 0.07^{\mathrm{b}}$ & $3.26 \pm 0.14^{c}$ \\
\hline Direct bilirubin (mg/dl) & $0.41 \pm 0.02^{\mathrm{d}}$ & $2.02 \pm 0.05^{\mathrm{a}}$ & $1.34 \pm 0.06^{\mathrm{b}}$ & $0.87 \pm 0.02^{\mathrm{c}}$ \\
\hline ALP (IU/L) & $68 \pm 2.12^{\mathrm{d}}$ & $111.80 \pm 2.70^{\mathrm{a}}$ & $95.40 \pm 1.77^{\mathrm{b}}$ & $80 \pm 1.81^{c}$ \\
\hline T.proteins (g/dl) & $7.49 \pm 0.20^{\mathrm{a}}$ & $4.18 \pm 0.18^{d}$ & $5.89 \pm 0.06^{c}$ & $6.78 \pm 0.14^{\mathrm{b}}$ \\
\hline Albumin (g/dl) & $3.95 \pm 0.076^{\mathrm{a}}$ & $1.99 \pm 0.025^{\mathrm{d}}$ & $2.75 \pm 0.036^{c}$ & $3.15 \pm 0.038^{b}$ \\
\hline $\begin{array}{l}\text { Globulins ( } \mathrm{g} / \mathrm{dl} \text { ) } \\
\text { abcd Means with differents }\end{array}$ & $3.53 \pm 0.13^{\mathrm{ab}}$ & $2.19 \pm 0.18^{c}$ & $3.14 \pm 0.07^{b}$ & $3.63 \pm 0.17^{\mathrm{a}}$ \\
\hline
\end{tabular}

Table 3: Effect of cranberry extract on serum creatinine and urea levels in normal and experimental groups of rats.

\begin{tabular}{|c|c|c|c|c|}
\hline Groups parameters & Normal group & $\begin{array}{l}\text { Positive control } \\
\text { (lead acetate } 50 \mathrm{mg} / \\
\text { kg.b.w.) }\end{array}$ & $\begin{array}{l}\text { Lead acetate }(50 \mathrm{mg} / \\
\text { kg.b.w. })+ \text { Cranberry } \\
\text { extract }(75 \mathrm{mg} / \mathrm{kg})\end{array}$ & $\begin{array}{l}\text { Lead acetate }(50 \mathrm{mg} / \\
\mathrm{kg} . \mathrm{b} . \mathrm{w} .)+ \text { Cranberry extract } \\
(150 \mathrm{mg} / \mathrm{kg})\end{array}$ \\
\hline Creatinine (mg/dl) & $0.77 \pm 0.022^{\mathrm{d}}$ & $1.93 \pm 0.007^{\mathrm{a}}$ & $1.31 \pm 0.039^{b}$ & $0.98 \pm 0.011^{\mathrm{c}}$ \\
\hline Urea (mg/dl) & $23.24 \pm 0.80^{d}$ & $53.38 \pm 0.99^{a}$ & $43.04 \pm 1.06^{b}$ & $34.78 \pm 0.83^{c}$ \\
\hline
\end{tabular}

Table 4: Effect of cranberry extract on serum total cholesterol (TC), triglycrides (TG), HDL-C, LDL-C and VLDL-C levels in normal and experimental groups of rats.

\begin{tabular}{|c|c|c|c|c|}
\hline Groups parameters & Normal group & $\begin{array}{l}\text { Positive control (lead } \\
\text { acetate } 50 \mathrm{mg} / \mathrm{kg} . \text { b.w.) }\end{array}$ & $\begin{array}{l}\text { Lead acetate }(50 \mathrm{mg} / \\
\text { kg.b.w. })+ \text { Cranberry } \\
\text { extract }(75 \mathrm{mg} / \mathrm{kg})\end{array}$ & $\begin{array}{l}\text { Lead acetate }(50 \mathrm{mg} / \\
\text { kg.b.w. })+ \text { Cranberry } \\
\text { extract }(150 \mathrm{mg} / \mathrm{kg})\end{array}$ \\
\hline $\mathrm{TC}(\mathrm{mg} / \mathrm{dl})$ & $91.6000 \pm 2.01494^{\mathrm{d}}$ & $141.80 \pm 1.88149^{a}$ & $120.80 \pm 1.24097^{\mathrm{b}}$ & $103.00 \pm 3.27109^{c}$ \\
\hline TG $(\mathrm{mg} / \mathrm{dl})$ & $67.0 \pm 2.93^{c}$ & $101 \pm 2.46^{\mathrm{a}}$ & $87.60 \pm 2.15^{b}$ & $80.8 \pm 1.35^{\mathrm{b}}$ \\
\hline HDL-C (mg/dl) & $54.80 \pm 1.77^{\mathrm{a}}$ & $27.40 \pm 1.20^{\mathrm{d}}$ & $39.60 \pm 1.86^{c}$ & $49.60 \pm 1.88^{\mathrm{b}}$ \\
\hline LDL-C (mg/dl) & $23.40 \pm 1.76^{\mathrm{d}}$ & $94.20 \pm 2.92^{\mathrm{a}}$ & $63.68 \pm 2.71^{b}$ & $37.24 \pm 4.76^{c}$ \\
\hline VLDL-C (mg/dl) & $13.44 \pm 0.60^{c}$ & $20.20 \pm 0.49^{\mathrm{a}}$ & $17.52 \pm 0.43^{b}$ & $16.14 \pm 0.26^{b}$ \\
\hline
\end{tabular}


The results displayed in (Table 5) showed a significantly difference in serum glucose, triiodothyronine (T3), total thyroxine (T4) as well as tumor necrosis factor-alpha $(\mathrm{TNF}-\alpha)$ levels among the four treated groups $(\mathrm{P}<0.001)$. In comparison with normal control group, oral intake of lead acetate at a dose of $50 \mathrm{mg} / \mathrm{kg}$ led to a substantial rise in serum glucose and tumor necrosis factor-alpha $(\mathrm{TNF}-\alpha)$ levels as well as a significant reduction in serum triiodothyronine (T3) and total thyroxine (T4) levels. In comparison to the group that received lead acetate, addition of 75 and $150 \mathrm{mg} / \mathrm{kg}$ cranberry extract led to a marked decrease in serum glucose and tumor necrosis factoralpha (TNF- $\alpha$ ) levels as well as a marked rise in serum triiodothyronine (T3) and total thyroxine (T4) levels.

Effect on antioxidant parameters in hepatic and renal tissue The findings in (Table 6) indicated a significantly difference in reduced glutathione (GSH) level, superoxide dismutase
(SOD), catalase activity (CAT), malondialdehyde (MDA) and total antioxidant capacity (TAC) in hepatic and renal tissue of the four assessment groups where $(\mathrm{P}<0.001)$. In comparison with normal control group, oral intake of lead acetate at a dose of $50 \mathrm{mg} / \mathrm{kg}$ led to a marked reduction in reduced glutathione (GSH) level, superoxide dismutase (SOD), catalase activity (CAT) and total antioxidant capacity (TAC) of hepatic and renal tissues. Also, the level of malondialdehyde (MDA) has increased significantly in hepatic and renal tissues. In comparison to the group that received lead acetate, addition of 75 and $150 \mathrm{mg} /$ $\mathrm{kg}$ cranberry extract led to a marked development in reduced glutathione (GSH) level, superoxide dismutase (SOD), catalase activity (CAT) as well as total antioxidant capacity (TAC) in hepatic and renal tissue. Also, the level of malondialdehyde (MDA) has decreased significantly in hepatic and renal tissues.

Table 5: Effect of cranberry extract on serum glucose, triiodothyronine (T3), total thyroxine (T4) and tumor necrosis factor-alpha (TNF- $\alpha$ ) levels in normal and experimental groups of rats.

\begin{tabular}{|c|c|c|c|c|}
\hline Groups parameters & Normal group & $\begin{array}{l}\text { Positive control (lead } \\
\text { acetate } 50 \text { mg/kg.b.w.) }\end{array}$ & $\begin{array}{l}\text { Lead acetate }(50 \mathrm{mg} / \\
\text { kg.b.w.) + Cranberry } \\
\text { extract }(75 \mathrm{mg} / \mathrm{kg})\end{array}$ & $\begin{array}{l}\text { Lead acetate }(50 \mathrm{mg} / \\
\text { kg.b.w. })+ \text { Cranberry } \\
\text { extract }(150 \mathrm{mg} / \mathrm{kg})\end{array}$ \\
\hline Glucose (mg/dl) & $86 \pm 2.44^{\mathrm{d}}$ & $162 \pm 2.77^{\mathrm{a}}$ & $132 \pm 3.44^{\mathrm{b}}$ & $107.8 \pm 2.81^{\mathrm{c}}$ \\
\hline T3 (ng/ml) & $0.438 \pm 0.04^{\mathrm{a}}$ & $0.101 \pm 0.01^{\mathrm{d}}$ & $0.178 \pm 0.01^{\mathrm{c}}$ & $0.331 \pm 0.01^{b}$ \\
\hline $\mathrm{T} 4$ (nmol/L) & $11.52 \pm 0.27^{\mathrm{a}}$ & $2.42 \pm 0.13^{\mathrm{d}}$ & $5.34 \pm 0.25^{c}$ & $8.86 \pm 0.10^{\mathrm{b}}$ \\
\hline TNF- $\otimes(\mathrm{pg} / \mathrm{ml})$ & $2.13 \pm 0.080^{d}$ & $12.61 \pm 0.43^{\mathrm{a}}$ & $8.02 \pm 0.11^{b}$ & $5.18 \pm 0.06^{c}$ \\
\hline
\end{tabular}

Table 6: Effect of cranberry extract on reduced glutathione (GSH), superoxide dismutase (SOD), catalase activity (CAT), malondialdehyde (MDA) and total antioxidant capacity (TAC) levels in hepatic and renal tissue of normal and experimental groups of rats.

\begin{tabular}{|c|c|c|c|c|}
\hline Groups parameters & Normal group & $\begin{array}{l}\text { Positive control } \\
\text { (lead acetate } 50 \mathrm{mg} / \\
\text { kg.b.w.) }\end{array}$ & $\begin{array}{l}\text { Lead acetate }(50 \mathrm{mg} / \\
\mathrm{kg} . b . w .)+ \text { Cranberry } \\
\text { extract }(75 \mathrm{mg} / \mathrm{kg})\end{array}$ & $\begin{array}{l}\text { Lead acetate }(50 \mathrm{mg} / \\
\mathrm{kg} . b . w .)+ \text { Cranberry } \\
\text { extract }(150 \mathrm{mg} / \mathrm{kg})\end{array}$ \\
\hline \multicolumn{5}{|l|}{ (Hepatic tissue) } \\
\hline GSH (nmol/g. tissue) & $2.80 \pm 0.032^{\mathrm{a}}$ & $0.78 \pm 0.022^{\mathrm{d}}$ & $1.28 \pm 0.097^{c}$ & $1.94 \pm 0.079^{\mathrm{b}}$ \\
\hline SOD (U/g. tissue) & $3.70 \pm 0.06 \mathrm{a}$ & $1.09 \pm 0.078^{d}$ & $1.94 \pm 0.025^{c}$ & $2.81 \pm 0.047^{b}$ \\
\hline CAT (U/g. tissue) & $1.82 \pm 0.030^{a}$ & $0.77 \pm 0.026^{d}$ & $1.13 \pm 0.046^{c}$ & $1.45 \pm 0.032^{\mathrm{b}}$ \\
\hline MDA (mmol/g. tissue) & $16.22 \pm 0.27^{\mathrm{d}}$ & $40.96 \pm 0.51^{a}$ & $28.36 \pm 0.73^{b}$ & $20.18 \pm 0.32^{c}$ \\
\hline TAC (mM/g. tissue) & $1.26 \pm 0.030^{\mathrm{a}}$ & $0.58 \pm 0.026^{\mathrm{d}}$ & $0.87 \pm 0.015^{\mathrm{c}}$ & $1.08 \pm 0.024^{b}$ \\
\hline \multicolumn{5}{|l|}{ (Renal tissue) } \\
\hline GSH (nmol/g. tissue) & $2.14 \pm 0.067^{\mathrm{a}}$ & $0.66 \pm 0.019^{d}$ & $1.06 \pm 0.083^{c}$ & $1.75 \pm 0.055^{b}$ \\
\hline SOD (U/g. tissue) & $3.07 \pm 0.032^{\mathrm{a}}$ & $1.94 \pm 0.059^{c}$ & $2.39 \pm 0.161^{\mathrm{b}}$ & $2.89 \pm 0.018^{\mathrm{a}}$ \\
\hline CAT (U/g. tissue) & $1.27 \pm 0.067^{\mathrm{a}}$ & $0.64 \pm 0.022^{\mathrm{d}}$ & $0.84 \pm 0.016^{c}$ & $1.06 \pm 0.049^{b}$ \\
\hline MDA (mmol/g. tissue) & $12.02 \pm 0.48^{\mathrm{d}}$ & $32.80 \pm 1.13^{a}$ & $21.26 \pm 0.70^{\mathrm{b}}$ & $16.42 \pm 0.35^{\mathrm{c}}$ \\
\hline TAC (mM/g. tissue) & $1.10 \pm 0.037^{\mathrm{a}}$ & $0.66 \pm 0.034^{c}$ & $0.75 \pm 0.018^{c}$ & $0.89 \pm 0.024^{b}$ \\
\hline
\end{tabular}


Table 7: Histological lesion score among different experimental groups of rats.

\begin{tabular}{|c|c|c|c|c|}
\hline Groups lesion & $\begin{array}{l}\text { Normal } \\
\text { group }\end{array}$ & $\begin{array}{l}\text { Positive control } \\
\text { (lead acetate } 50 \\
\text { mg/kg.b.w.) }\end{array}$ & $\begin{array}{l}\text { Lead acetate }(50 \mathrm{mg} / \\
\text { kg.b.w. })+ \text { Cranberry ex- } \\
\text { tract }(75 \mathrm{mg} / \mathrm{kg})\end{array}$ & $\begin{array}{l}\text { Lead acetate }(50 \mathrm{mg} / \\
\text { kg.b.w. })+ \text { Cranberry ex- } \\
\text { tract }(150 \mathrm{mg} / \mathrm{kg})\end{array}$ \\
\hline \multicolumn{5}{|l|}{ (Liver) } \\
\hline Congested blood vessels and sinusoids & - & +++ & ++ & ++ \\
\hline Degenerated hepatocytes & - & ++++ & +++ & + \\
\hline Inflammatory cells aggregations & - & ++++ & - & - \\
\hline Portal fibrosis & - & ++ & - & - \\
\hline Kupffer cells hyperplasia & - & - & ++ & + \\
\hline Diplocytes (Regenerative attampts) & - & - & + & +++ \\
\hline \multicolumn{5}{|l|}{ (Kidney) } \\
\hline Necrotic glomeruli & - & ++ & - & - \\
\hline Shrunken/lobulated glomeruli & - & +++ & +++ & - \\
\hline Tubular casts & - & +++ & + & - \\
\hline Hemorrhages & 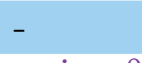 & ++++ & - & - \\
\hline
\end{tabular}

\section{HistopATHOLOGICAL FINDINGS OF LIVER AND KIDNEY} TISSUE IN DIFFERENT GROUPS OF RATS

Table 7 and Figure 1 Representative Photomicrograph of rats liver ( $\mathrm{H}$ and E, X400) demonstrating: (A) Structures of normal hepatic tissue. (B) Inflammatory accumulations replace necrotic liver cells (star). (C) Interlobular fibrotic strands (star). (D) Portal fibrosis besides congested blood vessels and proliferated bile duct epithelium (star), (E) Restore normal hepatocytes and hyperplastic kupffer cells with a few hepatocytes appeared apoptosis (arrow). (F) Apparently normal hepatocytes with prominent diplocytes (arrow) with still slight congested blood vessels. A) Control, B, C and D) Lead toxicity, E) Lead + Cranberry $(75 \mathrm{mg})$, Lead + Cranberry $(150 \mathrm{mg}) \mathrm{n}=10$.

Table 7 and Figure 2 representative photomicrograph of rats kidney ( $\mathrm{H}$ and E, X400) demonstrating: (A) Structures of normal renal tissue. (B) Renal tubules with severe necrosis and glomeruli (arrow) besides edema infiltrated with inflammatory cells (star). (C) Degenerated renal tubules, interstitial inflammatory cells infiltrations, extravasated erythrocytes (star) and vasculitis characterized by endotheliosis and vacuolar media (arrow). (D) Prominent homogenous more eosinophilic cats in the convoluted renal tubules (arrow), (E) remodeling the majority renal structures with regenerated attapts (arrow). (F) Apparently normal renal glomeruli and proximal tubules. A) Control, B, C and D) Lead toxicity, E) Lead + Cranberry $(75 \mathrm{mg})$, Lead + Cranberry (150mg) $n=10$.

There is various type of heavy metals within the ecosystem (waters, soil and dust) and this cannot be degraded. The key sources of heavy metals are various forms of anthropogenic practices including mining, melting and various types of industrial trash (Wu et al., 2015). Earth 's crust usually contains heavy metals in trace quantities, however in several aspects of everyday lives are they used, for example, Putters, self-washing ovens, vehicles, disinfectants, plastics, phones, sunlight power plates, fuel cells, as well as several other things (Karthik et al., 2016).

Heavy metals that count lead constitute a significant health hazard to living creatures (Abou-Kassem et al., 2016; Khafaga, 2017; Saad et al., 2018). Throughout most aspects of nature, lead as well as other heavy metals are noticeable in conjunction with many other elements at very small pollution levels; thus, the existence of lead in the ecosystem does not perform any function in physiological systems. It might result in permanent health problems with a high rate of morbidity, like hepatic, nervous, and renal system diseases (Murata et al., 2009; Ekanem et al., 2015). Extreme lead poisoning causes problems with body function, including neurological, cardiovascular, hematologic, and reproductive issues. Elevated blood lead concentrations trigger the central nervous system (CNS) to malfunction, resulting in encephalopathy and edoema, which directly targets the cerebellum (Rao et al., 2014; Pal et al., 2015). Pregnant women who have an elevated concentrations of lead in their bodies may have abortion. Males' potency was reduced when they were exposed to lead for a long time (Vigeh et al., 2011; Amadi et al., 2017).

Use of phytonutrients in the last years to protect against the dangers of environmental toxic substances has been viewed as a promising pharmacological strategy to maintain health of the body without side effects (Kumar et al., 2009). According to Vinson et al. (2001), cranberries' antioxidant properties are unique among fruits in terms 
of quality and quantity of antioxidants because they contain a high concentration of flavonoids and phenolic acids. Therefore, the goal of this work aimed to investigate if cranberry extract could protect rats from hepato-renal toxicity caused by lead acetate.

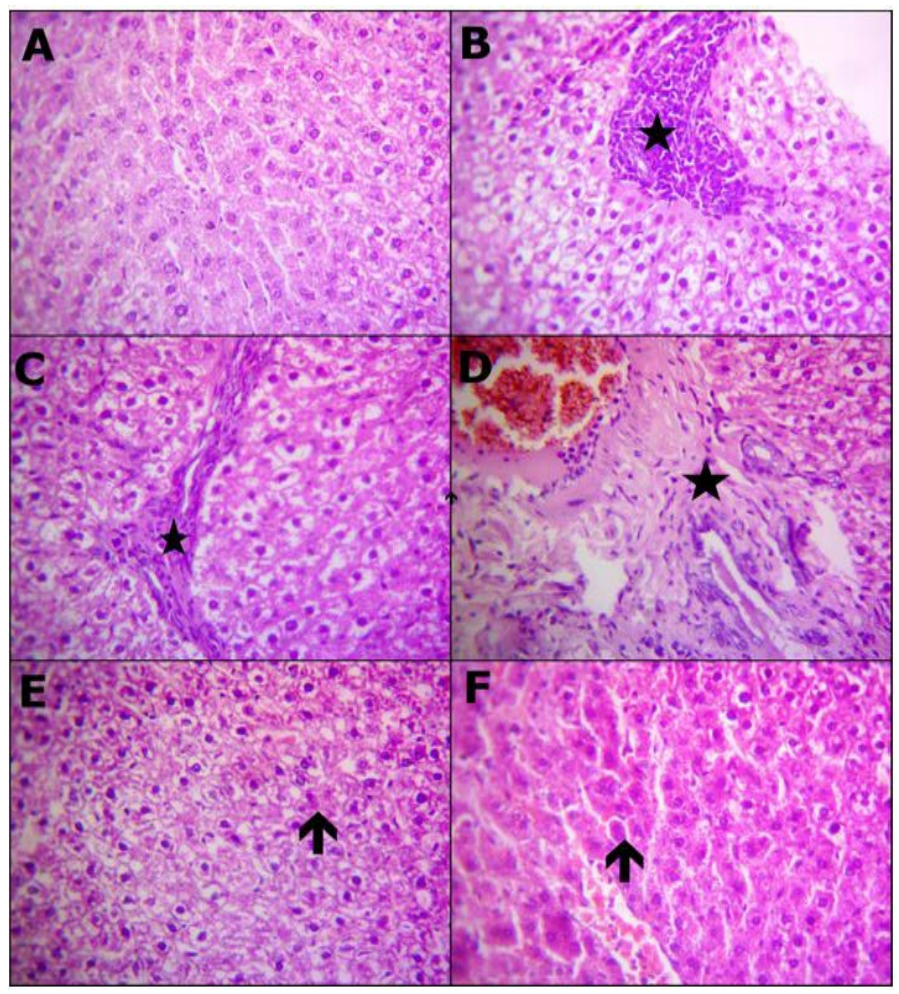

Figure 1: Reprehensive photomicrograph of rats liver ( $\mathrm{H}$ and E,X400) showing; (A) Normal hepatic micromorphological structures; (B) Necrosis hepatocytes replaced by inflammatory aggregations (star); (C) Interlobular fibrotic strands (star); (D) Portal fibrosis besides congested blood vessels and proliferated bile duct epithelium (star); (E) Restore normal hepatocytes and heperplastic Kupffer cells with a few hepatocytes appeared apoptosis (arrow); (F) Apparently normal hepatocytes with prominent diplocytes (arrow) with still slight congested blood vessels. (A) Control; (B, C and D) Lead toxicity; (E) Lead + Cranberry (75mg), Lead + Cranberry $(150 \mathrm{mg}) \mathrm{n}=10$.

GC/MS results of cranberry extract revealed that major identified compounds were $29.33 \%$ of stearic acid and 10.44\% Palmitic acid; major constituents identified in extract were displayed in (Table 1). Our findings are consistent with some previous research, which identified stearic and palmitic acids as the major components of the cranberry extract's chemical composition (Pappas and Schaich, 2009; Glisan et al., 2016).

When compared to the normal group, the lead acetatecaused liver damage markedly raised serum liver enzymatic activity (ALT, AST, LDH, and ALP), also total soluble serum protein, albumin and globulin concentrations were reduced significantly, as well as a large rates of liver histologic alterations. Increased hepatic enzymes have been utilized as assays of hepatic injury. They enter bloodstream as a result of lipid oxidation caused by hepatic membrane stability loss induced by lead poisoning (Farida et al., 2012; Laamech et al., 2017). Since plasma proteins in the liver, particularly albumin, are mainly synthesized, a substantial decrease of total protein in serum indicated liver dysfunction (Abdel-Maksoud et al., 2015a). Furthermore, because lead binds to plasma proteins, it disrupts protein synthesis in hepatocytes, which leads to variations among large amount of enzymes of hepatocytes (Shalan et al., 2005). It moreover disrupts the signal of $\mathrm{Ca}^{2+}$ inside the cells, leading to endoplasmic reticulum's demolition and reducing free amino acids application to synthesize proteins (Moussa and Bashandy, 2008; BaSalamah et al., 2018). Comparable findings were observed in rats given sub-lethal doses of lead acetate $(1 / 20,1 / 40,1 / 60)$ by Ibrahim et al. (2012). Similar results in lead acetateintoxicated rats have been observed by El-Tantawy (2016) as well as Gargouri et al. (2017).

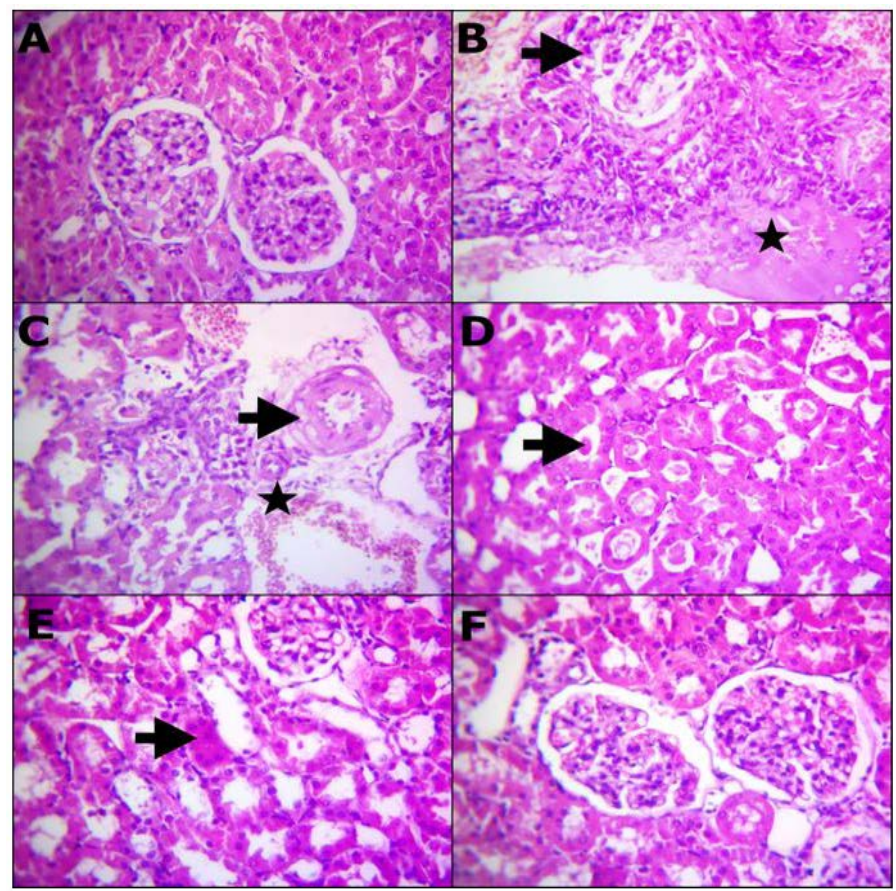

Figure 2: Reprehensive photomicrograph of rats Kidney ( $\mathrm{H}$ and $\mathrm{E}, \mathrm{X} 400$ ) showing; (A) Normal renal histomorphological structures; (B) Massive necrotic renal tubules and glomeruli (arrow) besides edema infiltrated with inflammatory cells (star); (C) Degenerated renal tubules, interstitial inflammatory cells infiltrarions, extravasated erythrocytes (star) and vasculitis characterized by endotheliosis and vacuolar media (arrow); (D) Prominent homogenous more eosinophilic cats in the convoluted renal tubules (arrow); (E) Remodeling the majority renal structures with regenerated attapts (arrow); (F) Apparently normal renal glomeruli and proximal tubules. (A) Control; (B, C and D) Lead toxicity; (E) Lead + Cranberry (75mg), Lead + Cranberry (150mg) n=10. 
In comparison to the group that received lead acetate, addition of 75 and $150 \mathrm{mg} / \mathrm{kg}$ cranberry extract led to a marked reduction in serum alanine aminotransferase (ALT), aspartate aminotransferase (AST), lactate dehydrogenase (LDH), total bilirubin, direct bilirubin, alkaline phosphatase (ALP) levels as well as a marked rise in serum total soluble protein, albumin and globulin levels.

The current investigation found increased serum ALT, AST, LDH, and ALP (a marker of hepatocyte damage) activities as a result of oxidative stress caused by $\mathrm{Pb}^{+2}$. These enhanced activities could be linked to the spilling of these enzymes into bloodstream from damaged hepatocytes due to altered membrane permeability of hepatocytes (Shohda et al., 2009). Increased serum ALP activities indicate cellular damage caused by a loss of cell membrane functional integrity. Hesperidin effectively reduced the blood accumulation of $\mathrm{Pb}^{+2}$ and showed that the polyphenols of cranberries chelate $\mathrm{Pb}^{+2}$. Furthermore, polyphenolic hydroxyl groups or their active metabolites could bind with $\mathrm{Pb}^{+2}$ and increase its excretion, lowering $\mathrm{Pb}^{+2}$ accumulation and reducing its toxicity. Hesperidin, a cranberry flavonoid, is well known for its antioxidant properties (Chanet et al., 2012), can remove excess $\mathrm{Pb}^{+2}$ from biological systems. Lipid metabolism modifications were triggered by $\mathrm{Pb}^{+2}$ and also serum and tissue lipids levels alterations. It is possible because $\mathrm{Pb}+2$ in the liver has accumulated, which is important for lipid homeostasis. Excess $\mathrm{Pb}^{+2}$ causes cellular damage and functional hepatocyte abnormalities through lipid peroxidation (Britton et al., 1987). Since the liver plays such an important role in maintaining lipid homeostasis, excess $\mathrm{Pb}^{+2}$ can alter serum lipid concentration, which can reduce or increase atherosclerosis risk.

In preclinical studies, serum creatinine and urea are proposed for assessing kidney injury because they are regarded the most specified and susceptible markers of renal failure. Serum creatinine and urea concentrations are often low in the bloodstream, however they rise once the renal become ill or injured. Most rises in serum creatinine and urea are due to renal injury (Moussa and Bashandy, 2008). This study demonstrated that rats fed lead acetate had higher concentrations of creatinine and urea leading to renal failure as compared to the normal control group. Ghoniem et al. (2012) made a same result, reporting that the treatment with lead acetate resulted in a considerable rise in serum creatinine and urea levels. In comparison to the group receiving lead acetate, intake of cranberry extract at a dose of 75 and $150 \mathrm{mg} / \mathrm{kg}$ led to a marked reduction of serum levels of creatinine and urea, showing that it would have a protective action of the kidneys versus renal toxicity caused by lead acetate. It could be because of its effective activity on lead acetate reactive oxygen species, which safeguards the kidney from tissue destruction through preserving membrane safety.

The significantly higher concentrations of total cholesterol and triglyceride of the lead acetate group had been caused whether by accelerated formation or reduced clearance, since lead is believed to trigger a lipoprotein cell surface receptor malfunction or restricted the enzymatic action of hepatic lipoprotein lipase (Liu et al., 2011). $\mathrm{Pb}^{+2}$ also decreased the cytochrome $\mathrm{P}-450$ action which is crucial to bile acid biosynthetic pathway, that is the primary pathway in the body in order to remove cholesterol (Newairy and Abdou, 2009; Dewanjee et al., 2013). Offor et al. (2017) have reported similar results.

Peroxidation of lipid might still destroy various cell membranes, causing changes in blood pressures as well as regulation of the heartbeat. Considering the fact that LDL cholesterol (LDL-C) levels are higher as well as HDL cholesterol levels are lower (HDL-C). Overloading iron caused an increase in total cholesterol as well as triglycerides, as previously reported by Dabbagh et al. (1994) and Brunet et al. (1999). The Fe+3 produced an increase in serum or tissue cholesterol was often caused by alterations of liver enzymes gene expression, primarily HMG-COA reductase. This HMG-COA enzyme genomic alteration induced by heavy metals were reported as well (Kojima et al., 2004). In Fe poisoned rats, increased plasma lipids (PLs) could be due to increased FFAs and cholesterol levels. Cranberry polyphenols reduced the unusual scattering of membrane lipids in circulatory system and the elevated production of further harmful peroxides, that induce severe alterations in tissues and cells, possibly due to their antioxidant properties. Howard and Kritchevsky (1997) clarified that decreased cardio-vascular risk is generally associated with phytochemicals that reduce the level of high cholesterol as well as triglycerides consumption.

In comparison with normal control group, oral intake of lead acetate at a dose of $50 \mathrm{mg} / \mathrm{kg}$ led to a substantial rise in serum glucose and tumor necrosis factor-alpha $(\mathrm{TNF}-\alpha)$ levels as well as a significant reduction in serum triiodothyronine (T3) and total thyroxine (T4) levels.

The pro-inflammatory cytokines in the liver (TNF- $\alpha$, IL-1 $\beta$, and IL6) were significantly upregulated after LA administration. Both BaSalamah et al. (2018) and Liu et al. (2018) reported that lead exposure promotes NF$\kappa \mathrm{B}$ activation and enhanced inhibiting phosphorylated adenosine monophosphate-activated protein kinase (AMPK), that subsequently increases reactive oxygen species and inflammatory cytokines in serum and tissues. These findings match those of El-Tantawy (2016), who found a substantial elevation in the values of tumor necrosis factor-alpha as well as caspase- 3 in the liver of rats exposed to lead acetate poisoning at a dose of $100 \mathrm{mg} / \mathrm{kg}$ 
each day up to four weeks. Likewise, Gargouri et al. (2017) and E1-Boshy et al. (2019) observed that rats exposed to lead acetate toxicity had greater levels of IL- $1 \beta, T N F-\alpha$, and IL-6 in serum.

In comparison to the group that received lead acetate, addition of 75 and $150 \mathrm{mg} / \mathrm{kg}$ cranberry extract led to a marked decrease in serum glucose and tumor necrosis factor-alpha (TNF- $\alpha$ ) levels as well as a marked rise in serum triiodothyronine (T3) and total thyroxine (T4) levels.

Following that, several genetic expressions such as cyclooxygenase-2 (COX-2) as well as inducible nitric oxide synthase (iNOS) were modulated, resulting in a reduction in tumor necrosis factor-alpha (TNF- $\alpha$ ) as well as Interleukin 1 beta (IL-1 $\beta$ ) production according to Hosseini and Hosseinzadeh (2018). These findings agree with those reported by Fu et al. (2008), and El-Sherbiny et al. (2010), as well as Ali et al. (2018), in which the proinflammatory serum TNF- $\alpha$ was decreased by cranberry extract.

In comparison with normal group, oral intake of lead acetate at a dose of $50 \mathrm{mg} / \mathrm{kg}$ led to a marked reduction in reduced glutathione (GSH) level, superoxide dismutase (SOD), catalase activity (CAT) and total antioxidant capacity (TAC) of hepatic and renal tissues. Also, the level of malondialdehyde (MDA) has increased significantly in hepatic and renal tissues.

Lead poisoning has a mechanistic and major role in the occurrence of oxidative stress possibly through increasing reactive oxygen species production and even exhausting the anti-oxidative enzymes strategy, as previously reported by El-Tantawy (2016); Laamech et al. (2017) and ElBoshy et al. (2019). Moreover, $\mathrm{Pb}^{+2}$ attaches permanently to the thiol group of GSH and is eliminated into the bile according to Ercal et al. (2001) and E1-Tantawy (2016). Moreover, it attaches toward additional SHhaving proteins, such as superoxide dismutase and catalase activity, lowering its function leading to increased lipid peroxidation as well as degradation of DNA, as previously reported by Andjelkovic et al. (2019). During this present investigation, rats subjected to lead acetate had a large increase in MDA values in both homogenized liver and kidney, as well as a substantial decrease in superoxide dismutase and catalase activity, and also a substantial drop in glutathione values. These findings were in agreement with BaSalamah et al. (2018). He found a large elevation in the values of malondialdehyde of liver and kidney, as well as a substantial drop in Glutathione Peroxidase and catalase activity, whereas superoxide dismutase was unaffected. Hepatic MDA was markedly increased in this context, while the levels of reduced glutathione as well as superoxide dismutase in the rats exposed to lead acetate toxicity were statistically decreased according to Baxla et al. (2013). In addition, Laamech et al. (2017) demonstrated that lead-exposed mice showed a marked decrease in the anti-oxidative enzymes of the liver including CAT, SOD, $\mathrm{GPx}$, and GSH as well as a rise in MDA levels. These results are in agreement with those reported by El-Sokkary et al. (2005); Mehana et al. (2012); Dewanjee et al. (2013) and Gargouri et al. (2017) as well.

In the present study, cranberry extract co-treatment at 75 and $150 \mathrm{mg} / \mathrm{kg}$ led to a marked increase in the levels of reduced glutathione (GSH), superoxide dismutase (SOD), catalase activity (CAT), as well as total antioxidant capacity (TAC) in the tissues of liver and kidney, also a marked reduction in malondialdehyde (MDA) levels in comparison to lead-acetate group, which shows a large enhancement in blood profile changes according to ElMaddawy and El-Sayed (2018). Moreover, liver injury was slightly lowered by CBE, which had been histologically indicated, as well as linked to limited improvement in liver enzymes, returned standard serum total protein, albumin, and globulin values, as well as decreased lipid peroxidation, as evidenced by lower MDA concentrations in the liver, as well as repaired superoxide dismutase and catalase activity. These findings possessed the capability of cranberry extract in maintaining cellular membranes as well as safeguarding tissues against destruction by free radicals, as well as enhancing the regeneration of damaged cells and hence decreasing transaminase and ALP release from the cytosol as previously reported by Abdel-Daim and Abdou (2015), El-Maddawy and El-Sayed (2018), Cheraghi and Roshanaei (2019) as well.

In comparison to control rats, the histopathological results demonstrated reversible degrading impacts affecting hepato-renal formation of rats subjected to lead-acetate toxicity, which could have been attributable to increased oxidative damage (Figure 1B-1D) and (Figure 2B2D). These degenerative changes have been observed on female albino rats following exposure to lead and because of oxidative damage as well as hepato-renal oxygen free radicals (Ghoniem et al., 2012). This investigation has demonstrated that lead acetate administration of leadacetate resulted in several hapatic histological changes, including PV obstruction, Kupffer cell hyperplasia, the inflammatory cell central region, blood sinusoidal contraction, and hepatocyte binucleation many histological changes in the liver, including PV congestion, Kupffer cell hyperplasia, focal area of inflammatory cells, contraction of blood sinusoids, as well as double nucleus formation of liver cells. Dehkordi et al. (2015); Omotoso et al. (2015) have reported similar results. The contact between $\mathrm{Pb}^{+2}$ and enzymes as well as tissue proteins involved in the liver, that mostly interacts with the anti-oxidative system 
and leads towards oxygen free radicals production, could cause hepatic inflammatory cells formation upon toxicity caused by lead-acetate. These could be used to simulate the reactions that cause inflammation according to Johar et al. (2004). Binucleation, as seen in this study, could be a response to cellular damage that typically shown through renewable cells (Gerlyng et al., 1993). Lead stimulates the phagocytic action of sinusoidal cells by increasing stellate sinusoidal macrophages in response to autophagy elevation often throughout liver tissue, which aids throughout eliminating removal of excessive $\mathrm{Pb}^{+2}$ as well as accompanying metabolites, according to findings of this study. The resulting hyperplasia of Kupffer cells is a detoxification defense technique (Ilić et al., 2014). Histopathological examinations of the liver reveal changes that indicate hepatic tissue destruction probably as a result of heavy metal cycling. Gajawat et al. (2005) clarified that toxic metal generate mercaptides containing cysteine's sulfhydryl group as well as weaker steady compounds among several chains of amino acids, which indicate hepatic tissue destruction.

Throughout comparing with $\mathrm{Pb}^{+2}$ rats treated group, Figure $1 \mathrm{E}$ revealed the big importance of using cranberry extract, which showed a significant improvement in histological structure of rats hepatic tissues as well as fewer pathogenic alterations. Cranberry extract has been shown to have identical improvements actions occurring in the rats hepatic tissues upon alterations caused by lead-acetate toxicity (Koriem, 2009).

Lead acetate administration resulted in glomerular changes, according to our histological examination of renal tissue. These changes included glomeruli atrophy and tubular epithelial cell degradation, which was consistent with previous research (Abdou and Hassan, 2014; Sharma and Singh, 2014). The cytoplasmic degradation noticed could be due to lysosomal hydrolytic enzyme leakage (Del Monte, 2005).

Cranberry extract has been shown to preserve histological integrity in destroyed liver and renal tissue with parenchyma necrosis, tubular expansion, and hyperemic conditions (Abdel-Maksoud et al.,2015b). The use of cranberry extract to lead-treated rats enhanced the structure and partially restored the investigated parameters to standard levels, as well as reducing the histopathological modifications rigidity (Figure 2E). Our observations appeared familiar to that by Abdel-Maksoud et al. (2015c) publications, showing similar interference impacts of excess iron in experimental rats.

Paracetamol-treated rats for hepatic tissues were found to have normal histoarchitecture after the use of cranberry extract, according to Abdel-Maksoud et al. (2015b).
The existence of flavonoids was discovered during a phytochemical preliminary examination of cranberry extract. Flavonoids (or bioflavonoids) are natural components that can modulate the enzymatic activity of catalase and superoxide dismutase as well as influence multiple cellular systems' behaviors. They also have antiinflammatory, antihepatotoxic, antitumor, anti-allergic, anti-osteoporosis and antioxidant properties (Ilić et al., 2014; Abdel-Maksoud et al., 2015a).

\section{CONCLUSIONS AND RECOMMENDATIONS}

In conclusion, the present study demonstrates that cranberry supplementation has protective effects against hepato-renal toxicity caused by lead acetate in rats. This could result from its antioxidant action, which includes the power of chelating ROS as well as prevent peroxidation of lipids, that can often cause cellular injury in the hepatorenal system. Furthermore, this could be a key toward the development of new free radical products that are both safe and effective.

\section{NOVELTY STATEMENT}

This study discovers the protective activity of cranberry extract that can be beneficial for the treatment of lead acetate-induced liver and renal toxicity. This study will help the researcher to uncover the critical areas that focus on evaluating of cranberry extract as a promising new agent in the treatment of certain type of liver and renal inflammation that many researchers were not able to explore. Thus, a new theory to explain the correlation between protective activity of cranberry extract and the level of antioxidant enzymes in liver and renal tissue may be arrived at.

\section{AUTHOR'S CONTRIBUTION}

Experimental design, antioxidant and hepato-renal-protective activities of cranberry extract were carried out by Hussein Ibrahim El-belbasy, Mohammed Abdalla Hussein, Mohamed El-mitwaly Alghitany. Wrote the protocol, wrote the first draft of the manuscript, managed the analyses of the study, managed the literature searches was carried out in collaboration between all authors.

\section{CONFLICT OF INTEREST}

The authors have declared no conflict of interest.

\section{REFERENCES}

-Abdel Moneim AE (2016). Indigofera oblongifolia prevents lead acetate-induced hepatotoxicity, oxidative stress, fibrosis and apoptosis in rats. PLoS One, 11(7): e0158965. 
-Abdel-Daim MM and Abdou RH (2015). Protective effects of diallyl sulfide and curcumin separately against thalliuminduced toxicity in rats. Cell J. (Yakhteh), 17(2): 379-388.

-Abdel-Maksoud AH, Mohammed AH, Afaf DA and Amira MA (2015c). Biochemical effect of cranberry extract on experimental toxicity with iron. Benha Vet. Med. J., 29(2): 60-73.

-Abdel-Maksoud AH, Mohammed AH, Raafat RM and Hanan TZ (2015b). Cranberry extract enhance antioxidant potential in ehrlich's ascites carcinoma bearing female albino mice. World J. Pharm. Sci., 3(3): 484-491.

-Abdel-Maksoud, H.A., Hussein MA and Barakat M (2015a). Cranberry extract as a functional food in treatment of myocardial toxicity induced by nicotine in Rats., 5(4): 11741180.

-Abdou HM, Hassan MA (2014). Protective role of omega-3polyunsaturated fatty acid against lead acetate-induced toxicity in liver and kidney of female rats. Biomed. Res. Int., pp. 435857.

-Abou-Kassem D, Mahrose K and Alagawany M (2016). The role of vitamin $\mathrm{E}$ or clay in growing Japanese quail fed diets polluted by cadmium at various levels. Animal, 10(3): 508519.

-Aebi H (1984). Catalase in vitro, 105: 121-126.

-Ahamed M, Siddiqui MK (2007). Low level lead exposure and oxidative stress. Curr. Opin., 383(1-2): 57-64.

-Ali BH, Al-Salam S, Al-Suleimani Y, Al-Kalbani J, Al-Bahlani S, Ashique M, Manoj P, Al Dhahli B, Al Abri N, Naser HT, Yasin J, Nemmar A, Al Za'abi M, Hartmann C and Schupp N (2018). Curcumin ameliorates kidney function and oxidative stress in experimental chronic kidney disease. Basic Clin. Pharmacol. Toxicol., 122(1): 65-73.

- Allain CC, Poon LS, Chan CS, Richmond W and Fu PC (1974). Enzymatic determination of total serum cholesterol. Clin. Chem., 20(4): 470-475.

-Amadi CN, Igweze ZN and Orisakwe OE (2017). Heavy metals in miscarriages and stillbirths in developing nations. Middle East Fert. Soc. J., 22(2): 91-100.

-Andjelkovic M, Buha Djordjevic A, Antonijevic E, Antonijevic B, Stanic M, Kotur-Stevuljevic J, Spasojevic-Kalimanovska V, Jovanovic M, Boricic N, Wallace D, Bulat Z (2019). Toxic effect of acute cadmium and lead exposure in rat blood, liver, and kidney. Int. J. Environ. Res. Publ. Hlth., 16(2): 274.

-ATSDR (2007). Toxicological profile for lead. In: Decision Support Systems; 557-573.

-ATSDR (2017). Lead toxicity case studies in environmental medicine. Case Stud. Environ. Med., (WB2832): 1-182.

- BaSalamah MA, Abdelghany AH, El-Boshy M, Ahmad J, Idris S and Refaat B (2018). Vitamin D alleviates lead induced renal and testicular injuries by immunomodulatory and antioxidant mechanisms in rats. Sci. Rep., 8(1): 1-13.

-Batton CJ and Crouch SR (1977). Spectrophotometer investigation of urea. Anal. Chem., 49: 464-469.

- Baxla SL, Gora RH, Kerketta P, Kumar N, Roy BK and Patra PH (2013). Hepatoprotective effect of Curcuma longa against lead induced toxicity in Wistar rats. Vet. World, 6(9): 664-667.

- Berbel P, Navarro D, Ausó E, Varea E, Rodríguez AE, Ballesta JJ, Salinas M, Flores E, Faura CC and de Escobar GM (2010). Role of late maternal thyroid hormones in cerebral cortex development. Exp. Model Hum. Premat., 20(6): 1462-1475.

- Beutler E, Duron O, Kelly BM (1963). Improved method for the determination of blood glutathione. J. Lab. Clin. Med.,

\section{1: 882 .}

- Beyaert R, Fiers W (1998). Tumor necrosis factor and lymphotoxin. In Cytokines, A.R.M.S. a. R. Thorpe, eds. Academic Press, San Diego. pp. 335-360. https://doi. org/10.1016/B978-012498340-3/50025-7

-Blumberg JB, Camesano TA, Cassidy A, Kris-Etherton P, Howell A, Manach C, Ostertag LM, Sies H, Skulas-Ray A, Vita JA (2013). Cranberries and their bioactive constituents in human health. Adv. Nutr., 4(6): 618-632.

-Britton RS, Bacon BR, Recknagel RO (1987).Lipid peroxidation and associated hepatic organelle dysfunction in iron overload. Chem. Phys. Lipids, 45(2-4): 207-239.

-Brunet S, Thibault L, Delvin E, Yotov W, Bendayan M, Levy E (1999). Dietary iron overload and induced lipid peroxidation are associated with impaired plasma lipid transport and hepatic sterol metabolism in rats. Hepatology, 29(6): 18091817.

- Buhl SN and Jackson KY (1978). Optimal conditions and comparison of lactate dehydrogenase catalysis of the lactate to pyruvate to lactate reactions in human plasma at 25,30 and $37^{\circ} \mathrm{C}$. Clin. Chem., 24(5): 828-831.

-Bukola RO, Adeleke AA, Omamuyovwi MI and Stephen OA (2015). Lead-induced damage on hepatocytes and hepatic reticular fibres in rats; protective role of aqueous extract of Moringa oleifera leaves (lam). J. Biosci. Med., 3: 27-35.

- Chanet A, Milenkovic D, Manach C, Mazur A, Morand C (2012). Citrus flavanones: What is the iron role in cardiovascular protection, J. Agric. Food Chem., 60(36): 8809-8822.

- Cheraghi E and Roshanaei K (2019). The protective effect of curcumin against aluminum chloride-induced oxidative stress and hepatotoxicity in rats. Pharm. Biomed. Res., 5(1): 11-18.

- Cheshchevik VT, Lapshina EA, Dremza IK, Zabrodskaya SV, Reiter RJ, Prokopchik NI, Zavodnik IB (2012). Rat liver mitochondrial damage under acute or chronic carbon tetrachloride-induced intoxication: protection by melatonin and cranberry flavonoids. Toxicol. Appl. Pharmacol., 261(3): 271-279.

- Costa C, Gangemi S, Giambò F, Rapisarda V, Caccamo D and Fenga $C$ (2015). Oxidative stress biomarkers and paraoxonase 1 polymorphism frequency in farmers occupationally exposed to pesticides. Mol. Med. Rep., 12(4): 6353-6357.

-Dabbagh AJ, Mannion T, Lynch SM, Frei B (1994). The effect of iron overload on rat plasma and liver oxidant status in vivo. Biochem. J., 300(3): 799 -803.

-Dapul H, Laraque D (2014). Lead poisoning in children. Adv. Pediatr., 61(1): 313-33.

-Dehkordi KK, Dehkordi SK and Dehkordi RA (2015). Histopathological study of the rat liver exposed with lead acetate as a microscopic survey. Anim. Vet. Sci., 3: 141-143.

-Del Monte U (2005). Swelling of hepatocytes injured by oxidative stress suggests pathological changes related to macromolecular crowding. Med. Hypotheses., 64(4): 818825 .

-Dewanjee S, Sahu R, Karmakar S and Gangopadhyay M (2013). Toxic effects of lead exposure in Wistar rats: involvement of oxidative stress and the beneficial role of edible jute (Corchorus olitorius) leaves. Food Chem. Toxicol., 55: 78-91.

- Doumas BT and Biggs HG (1972). Standard methods of clinical chemistry, 7: 175-189.

- Ekanem AU, Kwari HD, Garba SH and Salami HA (2015). Effect of lead acetate on spleen and blood parameters in 
albino rats. IOSR J. Dent. Med. Sci. Ver. I., 14(3): 43-49.

-El-Boshy ME, Refaat B, Qasem AH, Khan A, Ghaith M, Almasmoum H, Mahbub A, Almaimani RA (2019). The remedial effect of Thymus vulgaris extract against lead toxicity-induced oxidative stress, hepatorenal damage, immunosuppression, and hematological disorders in rats. Environ. Sci. Pollut. Res. Int., 26(22): 22736-22746.

-El-Maddawy ZK and El-Sayed YS (2018). Comparative analysis of the protective effects of curcumin and $\mathrm{N}$-acetyl cysteine against paracetamol-induced hepatic, renal, and testicular toxicity in Wistar rats. Environ. Sci. Pollut. Res. Int., 25(4): 3468-3479.

-E1-Sherbiny M, Araffa A, Mantawy M, Hassan HM (2010). Protective role of curcumin against oxidative stress, immunosuppresive and cytotoxic effects of lead exposure. World Appl. Sci. J., 11: 1557-1562.

-E1-Sokkary GH, Abdel-Rahman GH and Kamel ES (2005). Melatonin protects against lead-induced hepatic and renal toxicity in male rats. Toxicology, 213(1-2): 25-33.

-El-Tantawy WH (2016). Antioxidant effects of Spirulina supplement against lead acetate-induced hepatic injury in rats. J. Tradit. Complement. Med., 6(4): 327-331.

-Ercal N, Gurer-Orhan H and Aykin-Burns N (2001). Toxic metals and oxidative stress. Part I: mechanisms involved in metals-induced oxidative damage. Curr. Top. Med. Chem., 1(6): 529-539.

- Farida T, Salawu OA, Tijani AY and Ejiofor JI (2012). Pharmacological evaluation of Ipomea asarifolia (Desr.) against carbon tetrachloride-induced hepatotoxicity in rats. J. Ethnopharmacol., 142(3): 642-646.

- Fenga C, Gangemi S, Giambò F, Tsitsimpikou C, Golokhvast $\mathrm{K}$, Tsatsakis A and Costa C (2016). Low-dose occupational exposure to benzene and signal transduction pathways involved in the regulation of cellular response to oxidative stress. Life Sci., 147: 67-70.

-Flora G, Gupta D and Tiwari A (2012). Toxicity of lead: A review with recent updates; $5(2): 47-58$.

-Fossati P and Prencipe L (1982). Serum triacylglycerols determined colorimetrically with an enzyme that produces hydrogen peroxide. Clin. Chem., 28(10): 2077-2080.

- Friedewald WT, Levy RI and Fredrickson DS (1972). Estimation of the concentration of low-density lipoprotein cholesterol in plasma, without use of the preparative ultracentrifuge. Clin. Chem., 18(6): 499-502.

- Fu Y, Zheng S, Lin J, Ryerse J and Chen A (2008). Curcumin protects the rat liver from $\mathrm{CCl} 4$-caused injury and fibrogenesis by attenuating oxidative stress and suppressing inflammation. Mol. Pharmacol., 73(2): 399-409.

- Gajawat S, Sancheti G and Goyal P (2005). Vitamin C against concomitant exposure to heavy metal and radiation: A study on variations in hepatic cellular counts. Asian J. Exp. Sci., 19(2): 53-58.

- Gao H, Liu Y, Guan W, Li Q, Liu N, Gao Z, Fan J (2015). Hepatotoxicity and nephrotoxicity of organic contaminants in wastewater-irrigated soil. Environ. Sci. Pollut. Res., 22(5): 3748-3755.

- Gargouri M, Hamed H, Akrouti A, Christian M, Ksouri R and El-Feki A (2017). Immunomodulatory and antioxidant protective effect of Sarcocornia perennis L. (swampfire) in lead intoxicated rat. Toxicol. Mech. Methods, 27(9): 697-706.

- Gerlyng P, Abyholm A, Grotmol T, Erikstein B, Huitfeld THS, Stokke T, Seglen PO (1993). Binucleation and polyploidization patterns in developmental and regenerative rat liver growth. Cell Prolif., 26(6): 557-565.

- Ghoniem M, El-Sharkawy N, Hussein M and Moustafa G (2012). Efficacy of curcumin on lead induced nephrotoxicity in female albino rats. Am. Sci. J., 8(6): 502-510.

- Glisan SL, Ryan C, Neilson AP and Lambert JD (2016). Cranberry extract attenuates hepatic inflammation in highfat-fed obese mice. J. Nutr. Biochem., 37: 60-66.

-Ali H, Khan E (2017). Environmental chemistry in the twenty first century. Environ. Chem. Lett., 15(2): 329-346.

-Hafez MM, Al-Shabanah OA, Al-Harbi NO, Al-Harbi MM, AlRejaie SS, Alsurayea SM, Sayed-Ahmed MM (2014). Association between paraoxonases gene expression and oxidative stress in hepatotoxicity induced by $\mathrm{CCl} 14$ Oxid. Med. Cell Longev., pp. 893212. https://doi. org/10.1155/2014/893212

- Henry RJ (1974). Clinical chemistry: Principles and technics $\left(2^{\circ} \mathrm{Ed}\right)$. Harper and Row.

- Hisano M, Bruschini H, Nicodemo AC and Srougi M (2012). Cranberries and lower urinary tract infection prevention. Clinic, 67(6): 661-668.

- Hosseini A, Hosseinzadeh H (2018). Antidotal or protective effects of Curcuma longa (turmeric) and its active ingredient, curcumin, against natural and chemical toxicities: A review. Biomed. Pharmacother., 99: 411-421.

- Howard BV, Kritchevsky D (1997). Phytochemicals and cardiovascular disease. A statement for healthcare professionals from American heart association, Circulation, 95(11): 2591- 2593.

-Ibrahim NM, Eweis EA, El-Beltagi HS, Abdel-Mobdy YE (2012). Effect of lead acetate toxicity on experimental male albino rat. Asian Pac. J. Trop. Biomed., 2(1): 41-46.

-Ilić S, Stojiljković N, Veljković M, Veljković S, Stojanović G (2014). Protective effect of quercetin on Cisplatin-induced nephrotoxicity in rats. Med. Biol., 16(2): 71-75.

- Johar D, Roth JC, Bay GH, Walker JN, Kroczak TJ and Los M (2004). Inflammatory response, reactive oxygen species, programmed (necrotic-like an apoptotic) cell death and cancer. Rocz. Akad. Med. Biolynst., 49: 31-39.

- Karthik C, Oves M, Thangabalu R, Sharma R, Santhosh SB, Indra Arulselvi P (2016). Cellulosimicrobium funkeilike enhances the growth of Phaseolus vulgaris by modulating oxidative damage under Chromium (VI) toxicity. J. Adv. Res., 7(6): 839-850.

- Khafaga AF (2017). Exogenous phosphatidylcholine supplementation retrieves aluminium-induced toxicity in male albino rats. Environ. Sci. Pollut. Res., 24(18): 1558915598.

- Kojima R, Randall JD, Ho H, Manshio H, Suzuki Y, Gullans RS (2004). Regulation of expression of the stress response gene, identification of the tonicity response element and intracellular signalling pathways. Biochem. J., 380(3): 783794.

- Koracevic D, Koracevic G, Djordjevic V, Andrejevic S and Cosic V (2001). Method for the measurement of antioxidant activity in human fluids. Clin. Pathol., 54(5): 356-361.

- Koriem KMM (2009). Lead toxicity and the protective role of Cupressus sempervirens seeds growing in Egypt. Rev. Latinoamer. Quim., 37(3): 230-242.

- Kumar P, Prasad Y, Patra A, Ranjan R, Swarup D, Patra R, Ranjan R, Swarup D, Patra RC, Pal S (2009). Ascorbic acid, garlic extract and taurine alleviate cadmium-induced oxidative stress in freshwater catfish (Clarias batrachus). Sci. 
Total Environ., 407(18): 5024-5030.

-Kwon SY, Bae ON, Noh JY, Kim K, Kang S, Shin YJ, Lim KM, Chung JH (2015). Erythrophagocytosis of lead-exposed erythrocytes by renal tubular cells: Possible role in leadinduced nephrotoxicity. Environ. Health Perspect., 123(2): 120-127.

-Laamech J, El-Hilaly J, Fetoui H, Chtourou Y, Gouitaa H, Tahraoui A, Lyoussi B (2017). Berberis vulgaris L. effects on oxidative stress and liver injury in lead-intoxicated mice. J. Complement. Integr. Med., 14(1).

-Lapshina EA, Zamaraeva M, Cheshchevik VT, OlchowikGrabarek E, Sekowski S, Zukowska I, Golovach N.G., Burd V.N, Zavodnik I.B (2015). Cranberry flavonoids prevent toxic rat liver mitochondrial damage in vivo and scavenge free radicals in vitro. Cell Biochem. Funct., 33(4): 202-210

- Liu C, Mab J, Sun Y (2011). Protective role of puerarin on leadinduced alterations of the hepatic glutathione antioxidant system and hyperlipidemia in rats. Food Chem. Toxicol., 49(12): 3119-3127.

- Liu CM, Yang HX, Ma JQ, Yang W, Feng ZJ, Sun JM, Cheng C, Li J, Jiang H (2018). Role of AMPK pathway in leadinduced endoplasmic reticulum stress in kidney and in paeonol-induced protection in mice. Food Chem. Toxicol., 122: 87-94.

-Lopes AC, Peixe TS, Mesas AE and Paoliello MM (2016). Lead exposure and oxidative stress: A systematic review. Rev. Environ. Contam. Toxicol., 236: 193-238.

-Mashige F, Tanaka N, Maki A, Kamei S and Yamanaka M (1981). Direct spectrophotometry of total bile acids in serum. Clin. Chem., 27(8): 1352-1356.

-Mehana EE, Meki ARM and Fazili KM (2012). Ameliorated effects of green tea extract on lead induced liver toxicity in rats. Exp. Toxicol. Pathol., 64(4): 291-295.

- Mervat HG, Nabela IE, Mohamed MAH and Gihan GM (2012). Efficacy of curcumin on lead induced nephrotoxicity in female albino rats. J. Am. Sci., 8: 78-82.

- Moussa SA, Bashandy SA (2008). Biophysical and biochemical changes in the blood of rats exposed to lead toxicity. Rom. J. Biophys., 18: 123-133.

- Murata K, Iwata T, Dakeishi M, Karita K (2009). Lead toxicity: does the critical level of lead resulting in adverse effects differ between adults and children? J. Occup. Health, 51(1): 1-12.

- Newairy ASA, Abdou HM (2009). Protective role of flax lignans against lead acetate induced oxidative damage and hyperlipidemia in rats. Food Chem. Toxicol., 47(4): 813818.

- Nishikimi M, Roa NA, Yogi K (1972). Determination of superoxide dismutase in tissue homogenate. Biochem. Biophys. Res. Common., 46: 849-854.

- Offor SJ, Mbagwu HO, Orisakwe OE (2017). Lead induced hepato-renal damage in male albino rats and effects of activated charcoal. Front. Pharmacol., 8: 107.

- Ohkawa H, Ohishi W, Yagi K (1979). Assay for lipid peroxides in animal tissues by thiobarbituric acid reaction. Anal. Biochem., 95(2): 351-358.

- Omotoso BR, Abiodun AA, Ijomone OM, Adewole SO (2015). Lead-induced damage on hepatocytes and hepatic reticular fibresin rats; protective role of aqueous extract of Moringa oleifera leaves (Lam). J. Biosci. Med., 3(05): 27-35.

- Pal M, Sachdeva M, Gupta N, Mishra P, Yadav M, Tiwari A (2015). Lead exposure in different organs of mammals and prevention by curcumin-nanocurcumin: A review. Biol.
Trace Elem. Res., 168(2): 380-391.

-Pappas E, Schaich KM (2009). Phytochemicals of cranberries and cranberry products: Characterization, potential health effects, and processing stability. Crit. Rev. Food Sci. Nutr., 49(9): 741-781.

- Plaza PI, Uhart M, Caselli A, Wiemeyer G and Lambertucci SA (2018). A review of lead contamination in South American birds: The need for more research and policy changes; 16(4): 201-207.

- Rao JV, Vengamma B, Naveen T, Naveen V (2014). Lead encephalopathy in adults. J. Neurosci. Rural Pract., 5: 161163.

- Reitman S, Frankel S (1957). A colorimetric method for the determination of plasma oxaloacetic acid and glutamic pyruvic transaminases. Am. J. Clin. Pathol., 28(1): 56-63.

- Saad HM, Hassieb MM, Oda SS, Tohamy HG, Khafaga AF (2018). Histopathologic study on the effect of aluminium chloride on heart, liver and kidney of rabbits. Alexand. J. Vet. Med., 56(1): 102-109.

-Shalan MG, Mostafa MS, Hassouna MM, El-Nabi SE (2005). Amelioration of lead toxicity on rat liver with vitamin $\mathrm{C}$ and silymarin supplements. Toxicology, 206(1): 1-15.

-Sharma S, Singh B (2014). Lead acetate induce histopathological alterations in renal tissue of Balb-C mice. (Mus musculus). Int. J. Appl. Biol. Pharmaceut. Technol., 5: 23.

- Shatha HK, Nazarmuteb ZA, Moayad MU (2016). The effect of penicillamine in reducing the toxic effects of lead acetate on some blood parameters, liver functions and testicular tissue in male rats. Int. J. Pharm. Pharm. Res., 5: 22-40.

- Shih WJ, Bachorik PS, Haga JA, Myers GL, Stein EA (2000). Estimating the long-term effects of storage at$70 \mathrm{C}$ on cholesterol, triglyceride, and HDL-cholesterol measurements in stored sera. Clin. Chem., 46(3): 351-364.

- Shohda A, Maraghy EL, Sherine M (2009). Hepatoprotective potential of crocin and curcumin against iron overloadinduced biochemical alterations in rat. Asian J. Bus. Res., 3(5): 215-221.

-Soliman MM, Baiomy AA, Yassin MH (2015). Molecular and histopathological study on the ameliorative effects of curcumin against lead acetate-Induced hepatotoxicity and nephrotoxicity in wistar rats. Biol. Trace Elem. Res., pp. $1-12$.

- Sri AS, Giftania WS, Koerniasari (2017). Protective effect of curcumin on lead acetate-induced testicular toxicity in Wistar rats. Res. Pharm. Sci., 12(5): 381-390.

-Suvarna SK, Layton C and Bancroft JD (2018). Bancroft's theory and practice of histological techniques; $8^{\text {th }}$ ed., Churchill Livingstone. Elsevier, England.

-Tammas FK, Daniel ZD (2009). Long term augmentation with T3 in refractory major depression. J. Affect. Disord., 115(12): 230-233.

-Tietz NW (1983). IFCC methods for the measurement of catalytic concentration of enzymes. J. Clin. Chem. Clin. Biochem., 21: 731-748.

- Trinder P (1969). Determination of glucose in blood using glucose oxidase with an alternative oxygen acceptor. Ann. Clin. Biochem., 6(1): 24-27.

-Vigeh M, Smith DR, Hsu PC (2011). How does lead induce male infertility? Iran J. Reprod. Med., 9(1): 1-8.

-Vinson JA, Su X, Zubik L and Bose P (2001). Phenol antioxidant quantity and quality in foods: Fruits. J. Agric. Food Chem., 49(11): 5315-5321.

-WHO (2010). Exposure to lead: A major public health concern. 
-Wu Q, Leung JY, Geng X, Chen S, Huang X, Li H, Huang Z, Zhu L, Chen J, Lu Y (2015). Heavy metal contamination of soil and water in the vicinity of an abandoned e-waste recycling site: Implications for dissemination of heavy metals. Sci. Total Environ., 506: 217-225.

-Wieczorek-Da browska M, Tomza-Marciniak A, Pilarczyk B, Balicka-Ramisz A (2013). Roe and red deer as bioindicators of heavy metals contamination in north-western Poland.
Chem. Ecol., 29(2): 100-110.

-Xu J, Lian LJ, Wu C, Wang XF, Fu WY (2008). Lead induces oxidative stress, DNA damage and alteration of p53, Bax and Bcl-2 expressions in mice. Food Chem. Toxicol., 46: 1488-1494.

-Yatzidis HL (1977). An improved biuret reagent. Clin. Chem., 23(5): 908. 